\title{
ARTICLES
}

\section{THE SECOND DEATH OF ILYA PAVLOVITCH BJUSCHEFF: THE LEGAL POSITION OF PRISONERS, SPIES AND DESERTERS DURING WORLD WAR 1}

\author{
ELIZABETH CHADWICK*
}

\section{INTRODUCTION}

As 1917 began, Europe was at war. By March, Tsar Nicholas II of Russia had abdicated his throne in favour of his son, and firing had slowed between the German and Russian trenches. ${ }^{1}$ At about this time, Grischa Iljitch Paprotkin, ${ }^{2}$ or German Prisoner No 173, No 2 Company, decides to escape. ${ }^{3}$ With 16 months of captivity behind him, this former Russian Sergeant of the $118^{\text {th }}$ Regiment of Infantry, Knight of the Cross of St. George, ${ }^{4}$ begins his journey from a saw mill village prison camp in Navarischkij, to Vologda, in the Northeast steppes of Russia, to be reunited with his wife Marfa Ivanovna and child Jelisavetja. ${ }^{5}$

Grischa never reaches Vologda. In the course of his brief escape attempt, he meets Babka, ${ }^{6}$ who secures for him a disguise which consists of a coat, trousers, and identification tag, formerly the possessions of one Ilya Pavlovitch Bjuscheff, No 5 Company, $67^{\text {th }}$ Rifles, from Vilna - now deceased. ${ }^{7}$ Babka urges Grischa to claim to be one of the, by now, many Russian deserters, if re-captured.

The Case of Sergeant Grischa, first published by Arnold Zweig in 1927, is a fictional account of one man's doomed struggle to escape from the machinery of war. ${ }^{8}$ Grischa

* Ph D; Senior Lecturer, Nottingham Law School, Nottingham Trent University. This article was published previously in [1997] XXXVI (3-4) Revue de Droit Militaire et de Droit de la Guerre 97-117 and is republished here by the kind permission of the copyright owner.

1 The Revolution of March 1917 is also known as the February Revolution. M Gilbert, First World War (Harper Collins, 1995), p. 315. See infra n 33, and accompanying text.

2 The fictional scenario which follows is taken from A Zweig, The Case of Sergeant Grischa (hereinafter "Grischa") (Eric Sutton, trans) (Hutchinson, 1947).

${ }^{3} \mathrm{Ibid}, \mathrm{p}$ 18. Grischa's status is in fact that of a prisoner-of-war (hereinafter "POW").

4 Ibid, p 171.

${ }^{5}$ It is noted at this point in the war that the Eastern Front bulged from the Baltic coast to Upper Silesia, stretching towards the Duna and the Dnieper. To the south, Germany administered the area from Warsaw to Austrian territory. To the north, the Russians still held Riga and the land beyond the river. Ibid, p 50 .

'Babka, whose real name is "Anna Kyrillovna", tells him "we're Russians although we're Lithuanians". Ibid, pp 34, and 39 , respectively.

7 Ibid, p 44.

${ }^{8}$ Grischa is based on an incident in 1917, and recounted to Zweig by a German Unteroffizier serving in Russia. K Petersen, Literatur und Justiz in der Weimarer Republik (1988), p 197. The novel was a bestseller both nationally and internationally. Zweig also wrote a play on the subject. See G Wenzel (ed), Arnold Zweig 1887-1968: Werk und Leben in Dokumenten und Bildern (Aufbau-Verlag, 1978), p 160. I wish to thank Prof S R Giles for translating the relevant German materials. 
manages to reach the German garrison at Mervinsk, where, by Order of February 1917 from Major-General Schieffenzahn, Commander-in-Chief of the Army on the Eastern Front (called Ob-Ost for short),

[E]very Russian deserter who failed to report within 3 days of crossing the lines into the territory occupied by the German Armies to the nearest town-major, or the commander of the nearest military or police unit, was to be forthwith charged before a court martial, and within 24 hours of his sentence to be shot as a spy. ${ }^{9}$

This Order is posted in seven languages, but Grischa cannot read. On capture, and as instructed by Babka, he confesses to be Bjuscheff, a Russian deserter, rather than Grischa, an escaped prisoner-of-war (hereinafter "POW"). Grischa's, or Bjuscheff's, clothes and identification tag are taken for use by German spies, and he is given German ones: the jacket of Gunner Lewin (killed) and the trousers of a lorry driver who had received nine shrapnel bullets with his thigh and knee. ${ }^{10}$ In the prisoners' barracks where Grischa is now fed, warm and dry, "he is as neat, cheerful, and light-hearted as a fish heading for a weir". "He is duly convicted by court martial as the "spy" Bjuscheff.

On realising his fate, Grischa reveals his true identity, and in a short time his former camp guards from Navarischkij A Camp are summoned to Mervinsk, where they identify him. ${ }^{12}$ Grischa is now known to be an escaped POW rather than a spy/deserter liable to the death sentence in accordance with Orders. In Bialystok, where the Judicial Section of Ob-Ost Headquarters is located, the Grischa dossier is found to be in good order. The task now is to identify the proper court to deal with him for his escape attempt. However, Major-General Schieffenzahn, who considers Grischa's case to be "a political matter", intercedes in the legal process and orders the original sentence of the Divisional Court Martial to be upheld in the following terms:

$[\mathrm{H}]$ igher considerations make it undesirable that such identity should be successfully established, inasmuch as the Commander-in-Chief [Schieffenzahn] . . . is convinced that the legal aspect of the case is of very slight importance compared with the military and political interests involved. In order to maintain the prestige of our courts and in the interests of military discipline, it is necessary that the proposal to revise the condemned prisoner's sentence should be rejected as unwarranted, and further, as prejudicial to the interests of the State. ${ }^{13}$

Four months later (by now, the end of November 1917), Grischa is executed pursuant to the above grounds.

Grischa raises many issues, dealing in particular with the political and military policies which impacted on his treatment during this part of 1917. Nevertheless, the many legal rules which existed at the time to guide military behaviour are not dealt with by Zweig in his account of Grischa's trial by court martial and subsequent execution. It is thus the purpose of this article to explore both the history and theory of the laws of war as they pertained to POWs, spies and deserters prior to and during World War 1, and by means of this alternative perspective, to illuminate the background and events described in Grischa.

The structure of this article is as follows. First, the Hague Conventions and Regulations of 1899 and 1907 will be discussed with particular reference to the position

\footnotetext{
9 Grischa, op cit, supra n 2, p 78. See infra n 84.

10 Ibid, p 84 .

11 lbid, p 82

12 lbid, p 116.

$13 \mathrm{lbid}, \mathrm{p} 163$.
} 
of POWs, spies, and deserters under the Hague Regulations on Land Warfare of 1907. Secondly, the influence of the Geneva Conventions, and the role of the International Committee of the Red Cross (hereinafter "ICRC") during World War 1 with regard to POW camps will be examined. Thirdly, military practice at the time will be explored. Fourthly, the division of authority in enemy-occupied territory will be addressed in order to shed some light on the final outcome. It is concluded that while "Grischa had a case" in legal and humanitarian terms, ${ }^{14}$ the perspectives of wartime "necessity" reflected in Bjuscheff's second death were symptomatic of a deeper jurisprudential struggle - that between the state as creator, or as creature, of law. ${ }^{15}$

\section{THE HAGUE CONVENTIONS AND REGULATIONS}

\section{Background}

To begin in highly general terms, modern European wars were fought for a "just cause" until the 16th century, and the types of harm that a "just" (or Christian) belligerent could employ knew few restrictions. ${ }^{16}$ By the 18 th and 19 th centuries, conflicting views as to the limits of "justness" resulted in the causes of war being separated ultimately from the laws of war. This disassociation led in turn to the development of laws of war. ${ }^{17}$

As may be seen in the fragments of an essay on international law by Jeremy Bentham bearing the date $1786-1789,{ }^{18}$ the mid-18th century experienced a new reliance on reason. Reason required, Bentham felt, that for any given nation, the general utility of doing good rather than harm to other nations should be the object of international law, "having the regard which is proper to its own well-being". From this, Bentham extrapolated international rights and duties, the breach of which must result in war. Though war was viewed at the time as a means of self-help and thus an arm of the law, Bentham's fifth object in his international code "could be, to make such arrangements, that the least possible evil may be produced by war, consistently with the attainment of the good which is sought for". ${ }^{19}$

The community of nations which arrived at many of the basic principles of the modern laws of armed conflict consisted of 19th century "civilised", capitalist European states. ${ }^{20}$ As 19 th century capitalism evolved into imperialism, the

${ }^{14}$ In particular, the verdict was based on a fiction, ie, that Grischa de facto was Bjuscheff de jure.

is See, eg, Grischa, op cit supra n 2, pp 78-80, 102, 129-132, 222-228, 301-305. See also infra text entitled "The Division of Authority in Enemy-Occupied Territory".

${ }^{16}$ See, eg, S Moratiel V, "The Spanish School of the new law of nations" (September-October 1992) IRRC 416; P Haggenmacher, "Just War and Regular War in Sixteenth Century Spanish Doctrine", ibid, p 434; T E Holland, Lectures on International Law (T A Walker and W L Walker, eds) (Sweet \& Maxwell, 1933), pp $244 \mathrm{ff}$.

${ }^{17} \mathrm{P}$ Haggenmacher, loc cit supra n 16, p 440. See also K Ogren, "Humanitarian law in the 'Articles of War' decreed in 1621 by King Gustavus II Adolphus of Sweden" (July-August 1996) IRRC 438.

18 "Project of Perpetual Peace", in J Bowring (ed), The Works of Jeremy Bentham (1838-1843), 11 Vols, Pt 8, pp 537-554, excerpted in $\mathrm{H}$ Wheaton, History of the Law of Nations in Europe and America (Gould, Banks and Co, 1845 (reprinted 1973)), pp 328-344. The "line of common utility" is emphasised.

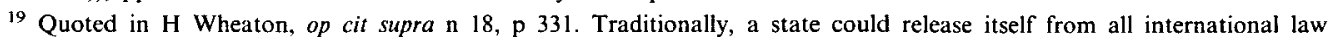
obligations except those relating to war's conduct by a declaration of war. Oppenheim's International Law Vol. II, $7^{\text {th }}$ ed, by H Lauterpacht (ed), (Longmans, 1952), p 179. Bentham's focus therefore would appear to be the common utility of mitigating the effects of war. Concurrent with the development of the principles of war law, the 19th century law of neutrality arose. See, eg, W Wheaton, op cit supra n 18, pp $290 \mathrm{ff}$; $\mathrm{H}$ Lauterpacht (ed), op cit supra this note, pp 624 ff; FE Smith, International Law (Dent (The Temple Primers), 1900), pp $131 \mathrm{ff}$; $\mathrm{T}$ Holland, op cit supra n 16, pp 395 $\mathrm{ff}$; W E Hall, A Treatise on International Law, $8^{\text {th }}$ ed, by A P Higgins (ed) (OUP, 1924), pp $691 \mathrm{ff}$.

${ }^{20}$ Rosas notes that "the increasing inter-dependence between these states, and the escalation of warfare, created an objective need for written rules common to the whole community", as determined in the last resort by the development of productive forces. A Rosas, The Legal Status of Prisoners of War: A Study in International Humanitarian Law Applicable in Armed Conflicts (Suomaleinen tiedeakatemia, 1976), pp 2, and 82, respectively. The laws of war were thus not considered applicable to, inter alia, the colonial wars of conquest. See, eg, Capt E Colby, "How to Fight Savage Tribes" 
corresponding monopolisation of production and capital resulted in part in more sophisticated developments in arms technology. ${ }^{21}$ An early attempt to control this new technology of warfare was made when Tsar Alexander II invited states to attend an International Military Commission in St. Petersburg, ${ }^{22}$ and the St Petersburg Declaration of 1868 was adopted. ${ }^{23}$ The Declaration states in pertinent part that the participating states had

[B]y common agreement fixed the technical limits at which the necessities of war ought to yieid to the requirements of humanity, ... [and] consider[ed] that the progress of civilisation should have the effect of alleviating as much as possible the calamities of war.

It is further stated in the Declaration that

The only legitimate object which states should endeavour to accomplish during war is to weaken the military forces of the enemy;

That for this purpose it is sufficient to disable the greatest possible number of men;

That this object would be exceeded by the employment of arms which uselessly aggravate the sufferings of disabled men, or render their death inevitable; ... .

As for more general attempts to codify the laws of war, the first may be said to have been the Lieber Code of $1863 .^{24}$ Issued by the United States War Department as US Army General Order No 100 to regulate the behaviour of the Northern Forces during the American Civil War (1861-1865), ${ }^{25}$ Article 15 provides in particular that "men who take up arms against one another in public war do not cease on this account to be moral beings, responsible to one another and to God". ${ }^{26}$

The Lieber Code in turn provided a format for subsequent projects to codify the laws of war, most notably, the Brussels Conference of $1874,{ }^{27}$ the Oxford Manual of $1880,{ }^{28}$ and the Hague Conventions and Annexed Regulations of 1899 and $1907 .^{29}$ In particular, both Hague Conferences expressed concern regarding evolving

(1927) 21 AJIL 279; J E Edmonds and L Oppenheim, Land Warfare: An Exposition of the Laws and Usages of War on Land, for the Guidance of Officers of His Majesty's Army (hereinafter "Land Warfare") (HMSO, 1912), Paragraph 38. Cf J Stone, Legal Controls of International Conflict (Stevens, 1954), p 549 n 11.

21 A Rosas, op cit supra n 20, p 28

${ }^{22}$ Seventeen states, including Russia, Prussia and the North German Federation, signed the St Petersburg Declaration in 1869. See D Schindler and J Toman (eds), The Laws of Armed Conflict (hereinafter "Schindler/Toman") (Sijthoff, 1973), pp 96-97.

${ }^{23}$ Reprinted in A Roberts and R Guelff (eds), Documents on the Laws of War (hereinafter "Roberts/Guelf") (Clarendon Press, 1989), at p 30. The St Petersburg Declaration prohibited the use of explosive projectiles under 400 grammes weight.

24 Reprinted in Schindler/Toman, with commentary, op cit supra n 22, at $\mathrm{p} 3$. The Instructions for the Government of Armies of the United States in the Field, or the Lieber Code, was issued by General Order dated 24 April 1863, and promulgated at the request of President Lincoln. Prepared by Francis Lieber, a German by birth, the Code corresponded "to a great extent to the laws and customs of war existing at the time". Ibid. See, eg, E Nys, "Francis Lieber-His Life and His Work" (Pt 2, 1911) 5 AJIL 355; J Miles, "Francis Lieber and the Law of War" (1990) XXIX-1-2 Revue de Droit Militaire et de Droit de la Guerre 253.

${ }^{25}$ See, eg, Q Wright, "The American Civil War, 1861-1865", in R Falk (ed), The International Law of Civil War (Johns Hopkins Press, 1971), pp 30, 54 n 37, 46 n 12; JG Randall and D Donald, The Civil War and Reconstruction (D C Heath, 2d ed 1961), pp 325-339; E Chadwick, “'Rights' and International Humanitarian Law”, in C Gearty and A Tomkins (eds), Understanding Human Rights (Mansell, 1995), pp 573, 575.

26 The following subjects, inter alia, are treated: rights of the captor in occupied countries, public and private property, protection of persons, deserters, prisoners of war, booty on the battlefield, partisans, spies, flags of truce, the exchange of prisoners, parole, armistice, capitulation, and insurrection.

27 The participating states which formulated the Project of an International Declaration concerning the Laws and Customs of War, reprinted in Schindler/Toman, op cit supra n 22, at p 25, were European. See, eg, G Werner, "Les prisonniers de guerre" (1928) 21 Recueil des Cours 5, 18. The Project provided the basis for the Oxford Manual, and is not to be confused with the "Declaration of the Institute of International Law", in 1875, regarding the Project. G Werner, ibid, pp 19-20. Articles 23-34 are devoted to POWs, and articles 19-22, to spies.

28 The Laws of War on Land. Manual Published by the Institute of International Law, provisions for POWs are provided primarily in articles 61-78, and regarding spies, in articles 23-26. Reprinted in Schindler/Toman, op cit supra n 22, at p 35. Neither the Brussels Project nor the Oxford Manual had any legal force.

29 The 1899 Peace Conference used the Brussels Project as the foundation for its work. The 1907 Hague Peace Conference "continued and completed" the work of the 1899 Conference. G. Werner, loc cit supra n 27, p 22. There were, however, 
war technology, and the preamble of Hague Convention II of 1899 and of Hague Convention IV of 1907 each expressed "the desire to serve, even in this extreme case [of war], the interests of humanity and the ever progressive needs of civilisation". Perhaps more importantly, the preamble reflected these many concerns by inclusion of the "de Martens Clause", the 1907 version of which reads as follows:

Until a more complete code of the laws of war can be issued, the High Contracting Parties think it expedient to declare that in cases not included in the Regulations adopted by them, populations and belligerents remain under the protection and the rule of the principles of the law of nations, as they result from the usages established between civilised nations, from the laws of humanity, and the requirements of the public conscience. ${ }^{30}$

As a final point by way of general background, the participation clause for the signatories to Hague Convention IV, found in article 2, provides as follows:

The provisions contained in the Regulations [annexed thereto] as well as in the present Convention, do not apply except between contracting Powers, and then only if all the belligerents are parties to the Convention. ${ }^{31}$

\section{POWS}

As 1917 began, Grischa was working as a POW at Navarischkij Camp, cutting wood in a saw mill village. Zweig does not give details of his original capture, only of his rank - that of Regimental Infantry Sergeant. ${ }^{32}$ Russian troops, despite an increase in the numbers of deserters from the Eastern Front, continued to engage in battle until Lenin's Decree of Peace of 8 November. ${ }^{33}$ As such, and pursuant to articles 4-20 of the 1907 Hague Regulations, Grischa, as a POW, would be held in protective custody,

fewer participants in 1907. Various forms of POW internment were contemplated in Hague Conventions II and III of 1899, and Hague Conventions IV, V, X, XI, and XIII of 1907. For purposes of brevity, the following instruments are referred to: 1899: Convention II regarding the laws and customs of war on land, and annexed Regulations; 1907: Convention IV respecting the laws and customs of war on land, and annexed Regulations. Chapter 2 of the Hague Regulations (articles 4-20) provides for the treatment and repatriation of POWs. These provisions borrow heavily from the Brussels Declaration of 1874. Hague Regulations articles 29-31 deal with spies. These conventions were not regarded as a complete code of the applicable law, leaving additional special arrangements to the belligerents. A Rosas, op cit supra n 20, p 76. For example, the Anglo-German accord of 2 July 1917, the French-German accords of December 1917 (also dated 15 March 1918) and April 1918, the Anglo-Ottoman accord of December 1917, the French-Ottoman accord of March 1918, all dealt with reprisals against POWs. See G Werner, loc cit supra n 27, p $101 \mathrm{n} 2$. See also the Final Act

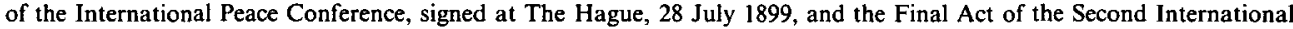
Peace Conference, signed at The Hague, 18 October 1907, reprinted in Schindler/Toman, op cit supra n 22, at pp 49, and 53, respectively; F E Smith, op cit supra n 19, Appendix A $\mathbf{n}$ M.

30 Reprinted in Roberts/Guelff, op cit supra n 23, p 45. Forty-one states signed Hague Convention IV on 18 October 1907.

31 Emphasis added. Hague Convention IV article 2, reprinted ibid, p 46. The text of the annexed Regulations is reprinted ibid, pp 48-57, the provisions of which are nearly identical with the 1899 Regulations. Hague Convention IV of 1907 was technically without binding force during World War 1 because signatories Serbia and Montenegro had not ratified it. All the belligerents were bound to Hague Convention II of 1899 until 8 August 1917. See G Werner, loc cit supra $\mathrm{n} 27$, p $96 \mathrm{n} 3$, citing the Bulletin International des Societes de la Croix-Rouge (1918), pp 25-26. Nevertheless, the majority of the belligerents had issued military manuals which largely reflected the standards in the Hague Regulations as well as the unwritten rules of acceptable military usage. See T E Holland, op cit supra n 16, pp 290-293; infra nn 65-82, and accompanying text.

32 Grischa, op cit supra n 2, p 171. The Hague Regulations provide for the qualification of belligerent combatants in articles 1-3; POW status flows from these requirements. Traditionally, a decision to grant POW status was evidence that (1) the war was international, and (2) the individual belonged to a category of persons entitled to commit hostilities. See A Rosas, op cit supra n 20, p 222 n 7; G Werner, loc cit supra n 27, pp 25, 39. The precise scope of protective legal guarantees for unprivileged combatants were, and remain, somewhat unclear. The requirement of express authorisation from a sovereign was apparently already abandoned by the time of the Brussels Project of 1874. See A Rosas, op cit supra n 20 , pp 419 , and 258 , respectively.

33 Armistice negotiations were finally concluded on 15 December, and fighting ceased on the Eastern Front. The war resumed on 18 February 1918 when German troops crossed the ceasefire line. The Russo-German peace treaty was finally signed on 3 March. See M Gilbert, op cit supra n 1, pp 343-401. At this point, Grischa, had he been alive, would have been entitled to repatriation. See infra text accompanying $n 42$. 
as "[p]risoners of war are in the power of the hostile Government, but not of the individuals or corps who capture them". ${ }^{34} \mathrm{He}$ could, in paraphrase, anticipate the following treatment: $:^{35}$

Article 4: Humane treatment, and the retention of ownership of non-military personal belongings. ${ }^{36}$

Article 5: Internment in a town, fortress, camp, or other place.

Article 6: The use of his labour (officers excepted) in work having no connection with the operations of war. His wages would go towards improving the conditions of his internment. ${ }^{37}$

Article 7: The same basic board, lodging, and clothing as provided to the German troops.

Article 8 merits quoting in full:

Prisoners-of-war shall be subject to the laws, regulations, and orders in force in the army of the State in whose power they are. Any act of insubordination justifies the adoption towards them of such measures of severity as may be considered necessary.

Escaped prisoners who are retaken before being able to rejoin their own army or before leaving the territory occupied by the army which captured them are liable to disciplinary punishment.

Prisoners who, after succeeding in escaping, are again taken prisoners, are not liable to any punishment on account of the previous flight. ${ }^{38}$

Article 9 obliged Grischa to inform his captors of his name and rank. ${ }^{39}$ Article $18^{40}$ afforded him a complete liberty in the exercise of religion. ${ }^{41}$ Article 19 provided that wills and death certificates would be received or drawn up, and burials conducted, in the same way as the capturing army. Article 20 provided that, after the conclusion of peace, repatriation would be carried out as soon as possible. ${ }^{42}$

\section{Spies}

Grischa, as Bjuscheff the deserter ${ }^{43}$ and presumed spy, could expect treatment guided by the 1907 Hague Regulations articles 29-31. Article 29 defines the word "spy", 44 one key to which is disguise. Hence, this rule implies that a soldier, not in disguise, who penetrates the hostile army's zone of operations, would not normally be

34 Hague Regulations, article 4(1).

35 Additional guidance regarding the treatment of POWs is contained in the 1907 Hague Regulations article 23, entitled "Means of Injuring the Enemy, Sieges, and Bombardments".

36 Although Grischa carried little with him in his escape from the saw mill camp, his personal possessions were safeguarded by his subsequent captors, and returned to him prior to his execution.

37 On release, the balance for work was to be paid over, after deducting the cost of the prisoner's maintenance.

38 [Emphasis added.] Grischa's escape was not successful: he neither rejoined his own army, nor did he cross from the lines of German-occupied territory. Grischa, op cit supra n 2, pp 50-78. He should thus have been subject only to disciplinary punishment. Werner notes that the absence of a more severe penalty for unsuccessful escapees was in order to prevent assimilation with deserters ("pour éviter notamment qu'elle [la tentative d'évasion] soit assimilée à la desertion devant l'ennemi"). G Werner, loc cit supra n 27, p 59.

39 Grischa initially passed himself off as Bjuscheff the deserter. However, his unsuccessful escape attempt meant that his status as a POW was a continuing one. Holland notes that the failure to disclose one's true name and rank is likely to result only in a curtailment of advantages granted to prisoners of one's class. T E Holland, op cit supra n 16, p 84l.

40 Articles 10-12 deal with the subject of parole, and article 13, with camp followers. Articles 14-16 concern prisoner inquiry offices, and relief societies. See infra nn 53-62, and accompanying text. Article 17 deals with officer rates of pay.

41 This was presumably facilitated by the Judeo-Christian heritage common to many of the relevant signatories to the Conventions.

42 See supra n 33.

43 See supra $n 7$.

44 "A person can only be considered a spy when, acting clandestinely or on false pretences, he obtains or endeavours to obtain information in the zone of operations of a belligerent, with the intention of communicating it to the hostile party". Article 29(1). 
considered a spy. ${ }^{45}$ And, in a manner similar to article $8(3)$ quoted above, is article 31:

A spy who, after rejoining the army to which he belongs, is subsequently captured by the enemy, is treated as a prisoner-of-war, and incurs no responsibility for his previous acts of espionage.

This immunity from prosecution by capturing enemy forces after the completion of a successful espionage operation indicates the lawfulness of employing spies and secret agents. On the other hand, "custom admits their punishment by death, although a more lenient penalty may be inflicted". 46

\section{THE GENEVA CONVENTIONS, AND ICRC ACTIVITES}

\section{Background}

The development of humanitarian, or Geneva, law somewhat paralleled that of the law of The Hague, but the two treaty bodies evolved in juridically distinct forms. Put simply, Hague law operates essentially to restrain the belligerents in the conduct of war operations, while Geneva law applies to safeguard protected persons not taking part in the hostilities. ${ }^{47}$ During World War 1, the 1864 Geneva Convention was in force between ratifying or adhering states. ${ }^{48}$ The new Hague system, on the other hand, applied only if all the belligerents were parties. ${ }^{49}$ The 1906 Geneva Convention for the Amelioration of the Condition of the Wounded and Sick in Armies in the Field adopted the Hague formula in article 24. States which were party to the 1864 Geneva Convention, but not that of 1906, applied the 1864 Convention.

The first Geneva Conference was convened in 1863. This gave impetus to subsequent Geneva Conferences in 1864 and $1906 .{ }^{50}$ What is particularly apparent however is the absence of any express protection for POWs under Geneva law at this time. ${ }^{51}$ Henry

45 Article 29(2) states as follows: "[t]hus, soldiers not wearing a disguise who have penetrated into the zone of operations of the hostile army, for the purpose of obtaining information, are not considered spies". While it could be argued that Grischa was indeed disguised in the clothes of Bjuscheff, it was in order to further his escape as a POW. On the other hand, Bjuschoff the deserter/spy would not have been in disguise, but instead, in his own uniform. He would however have been acting clandestinely by not reporting his presence within the requisite three days. The crux of the matter was to prove Bjuscheff had intended to obtain enemy military information. The mental element of intent required by article 29(1) was not made part of Schieffenzahn's Order. Cf infra n 85.

46 Land Warfare, op cit supra $\mathrm{n} 20$, paragraph 158. Land Warfare was prepared by its authors for the General Staff by order of His Majesty's Secretary of State for War. It was embodied from 1914 onwards in the official Manual of Military Law ( ${ }^{\text {th }}$ ed 1951). J Stone, op cit supra n 20, p $547 \mathrm{n} 1$. See infra $\mathrm{nn} 74-82$, and accompanying text. The death penalty is in fact what Schieffenzahn ordered in February 1917 for deserters who failed to declare their presence in Ob-Ost within three days, presumably on the basis that this implied spying. Supra $\mathrm{n}$ 9. This type of absolute prohibition takes into account neither the Hague requirement of a mental element, nor aspects of the surrounding circumstances, eg, the fact that Grischa could not read the posted warnings.

${ }^{47}$ See, eg, EP Syquia, "Dr Jean Pictet and International Humanitarian Law", in Studies and Essays in Honour of Jean Pictet (Nijhoff, 1984), pp 551, 555. The organisation established itself as an "International Committee for Relief to Wounded Military Personnel" in 1863. See G Willemin and R Heacock, The International Committee of the Red Cross (Nijhoff, 1984), p 19.

${ }^{48}$ See Geneva Convention for the Amelioration of the Condition of the Wounded in Armies in the Field, 1864, articles 8 and 9.

49 1899: Hague Convention II article 2, Convention III article 11. 1907: Hague Convention IV article 2, Convention V article 20, Convention X article 18, Convention XI article 9, Convention XIII article 28 . One reason for this was to ensure reciprocity and equality of arms. See supra $\mathrm{n} 31$.

so The results of which were the 1864 and 1906 Conventions, reprinted in Schindler/Toman with commentary, op cit supra n 22, pp 203, and 223, respectively. Military criticism of the 1864 Convention, by Bismarck for example, led to a Conference of Societies in Paris in 1867. Ratification of the Additional Articles was refused because some related to naval warfare. T E Holland, op cit supra n 16, pp.332-333. A proposal in 1868 to render infractions of the Convention penal under national Articles of War was also rejected by the European governments. W E Hall, op cit supra n 19, pp 482-483.

51 Instead, reference was made to the Hague Regulations which were considered to be incomplete, as well as to custom and acceptable military usage. See supra text accompanying n 30 . 
Dunant, the founder of the Red Cross movement, tried to place provisions specifically regarding POWs on the 1864 agenda, but failed. ${ }^{52}$ In 1869, the Second International Conference of the Red Cross, held in Berlin, adopted a resolution regarding the establishment of a correspondence and information bureau. ${ }^{53}$ Dunant worked for POW protection in Paris, during the Franco-German War (1870-1871), after which he multiplied his efforts in Paris and London for a convention. ${ }^{54}$ In spring 1874 , a draft convention on the treatment of POWs was submitted to governments for their consideration by the International Society for the Amelioration of the Condition of Prisoners of War, formed in 1872 and unrelated to the Red Cross. A preparatory conference was cancelled however when the Brussels Conference was called by the Russian government. ${ }^{55}$

Reference was made to the 1899 Hague Regulations when the Red Cross met in St. Petersburg, for its Seventh International Conference, and the issue was raised again at the Eighth International Conference in London, in $1907 . .^{56}$ The issue was effectively settled at the Ninth International Conference in Washington, in 1912. The Red Cross decided to take over the informational tasks authorised by article 14 of the Hague Regulations, as well as to entrust ICRC delegates with providing relief to POWs, as authorised in article 15. ${ }^{57}$ The 1906 Convention, however, brought voluntary assistance under the control of the belligerent employing it. ${ }^{58}$ The relevant bodies had already acted unofficially in this capacity during the German-Danish War of 1864, the Franco-German War of 1870-1871, and the Russo-Japanese conflict of 1904-1905, as well as during other conflicts of a more limited nature. ${ }^{59} \mathrm{~A}$ specific convention aimed at the protection and care of POWs was not to occur until 1929.60

52 A Rosas op cit supra n 20, p 69. Dunant subsequently delivered a report on the subject to the 1867 International Conference of the ICRC in Paris, in an effort to insert an additional article in the 1864 Convention to recognise the right of the ICRC to deal with POWs. Dunant's report was accepted by the Conference. G Werner, loc cit supra n 27 , pp 13-14.

53 This would lead to the establishment of the ICRC's Prisoners of War Agency in 1914, which was charged with collecting and transmitting information, and visiting internment camps. See P Abplanalp, "The International Conference of the Red Cross as a factor for the development of international humanitarian law and the cohesion of the International Red Cross and Red Crescent Movement" (September-October 1995) 308 IRRC 520, 526-527. An associated innovation during World War I was the introduction of "l'avis de capture" - a simple card on which the POW wrote his prisoner status, address, and state of health for forwarding to his family via the free system of post provided for in article 16 of the 1907 Hague Regulations. See G Werner, loc cit supra n 27, p 56. ICRC activities were partly founded on the conditional authorisation given in articles 14 and 15 of the Hague Regulations. A Rosas, op cit supra n 20, p 463. See also supra n 40.

$54 \mathrm{G}$ Werner, loc cit supra n 27, p 16. Dunant's efforts to involve the ICRC as an actor in conflicts were not supported by the Committee at this time, primarily because of its stance of political neutrality. Instead, the Committee felt that any presence in the field should be limited to the National Societies of the belligerents. G Willemin and R Heacock, op cit supra n 47, pp 23-24.

55 Supra $\mathrm{n}$ 27. The Brussels Project provisions on POWs were influenced by the International Society's draft. A Rosas, op cit supra n 20, p 69. However, many participants in the International Society were not invited to Brussels. $G$ Werner, loc cit supra n 27, p 17.

56 See P Abplanalp, loc cit supra n 53, pp 527-528.

57 Ibid, p 528. For an overview of the distinction between the respective roles of the national societies and the ICRC, see G Willemin and R Heacock, op cit supra $n 47$.

58 Articles 10-13. See W E Hall, op cit supra n 19, p 482 n 3.

s9 See P Abplanalp, loc cil supra n 53, p 528; A Rosas, op cit supra n 20, p 463. The Committee developed its first operational activities in 1870-1871 by creating in Basle an agency for information and relief to the sick and wounded in the French and Russian armies. This agency was designed to facilitate the exchange of information among National Societies and to be a centre for relief transmission. G Willemin and R Heacock, op cit supra $\mathrm{n} 47$, p 24.

60 The 1929 Geneva Convention relative to the Treatment of Prisoners of War supplemented rather than replaced the provisions on POWs contained in the Hague Regulations. Roberts/Guelff, op cit supra n 23, p 215. ICRC activity for the development of the Hague Regulations occurred after the war. The International Law Association also adopted a Code for the Treatment of POWs. See ILA Report of the 30th Conference (1921), pp 236-246. 


\section{Grischa}

The role assumed by the national Red Cross societies and the ICRC during World War 1 regarding the specific issue of the humanitarian treatment of POWs became, among other things, a means of observing the application by the belligerents of the Hague Regulations. Holland notes that the very magnitude of caring for POWs during such a protracted war as World War 1 meant that the burdens on Germany in this regard - particularly during the early years - were exceedingly heavy. Reports made available by neutral representatives indicate that "in a number of the German camps conditions were extremely bad, and that almost everywhere in Germany prisoners suffered very great privations through shortage of food and clothing". ${ }^{\circ}$

In Grischa's case, Zweig makes no mention of any particular hardship endured by the POW while in his second detention, other than personal psychological anguish caused by his fate. As for the informational functions of the Red Cross, there is no mention of any communication made to Grischa's wife of his imprisonment in Navarischkij saw mill camp or in Mervinsk, or of any correspondence passing between them. On the other hand, this could merely have been due partly to the deteriorating situation inside revolutionary Russia. There is however some mention of Red Cross delegates charged with camp inspections. In particular, delegates witness the handover of Grischa's possessions prior to his execution, and he is assured that "his wife will receive the pension of a sergeant who has fallen in action". ${ }^{2}$

\section{USAGE AND CUSTOM}

\section{Background}

As previously mentioned, ${ }^{63}$ none of the Hague Conventions dealt comprehensively with their subject matter, and as noted by the authors of the British Manual of Land Warfare, "the delicate questions of hostages and reprisals are not mentioned at all". ${ }^{64}$ Thus, in the discussion to follow, the impact of usage on the customary and written rules or laws of war, as outlined primarily in the Manual of Land Warfare (hereinafter "Land Warfare"), will be highlighted. ${ }^{65}$ The British manual also makes frequent reference to the French and German manuals concerning land warfare. ${ }^{66}$

61 T E Holland, op cit supra n 16, p 342. See also Hall, who notes that there was evidence during World War 1 of the Red Cross emblem being misused by the Germans for offensive purposes, seemingly under orders on many occasions. Allegations that the wounded were killed, and the Red Cross emblem abused, were also made. W E Hall, op cit supra n 19, p 484, citing the Report of the Committee on alleged German outrages, appointed by HBM's government, pp 59, 61 .

62 Grischa, op cit supra n 2, pp 321-323. See also ibid, p 215. The ICRC initiated such visits to POWs through the distribution of relief, extending them ultimately to other categories of detainees.

63 Supra n 30. See also Land Warfare, op cit supra n 20, paragraph $5 \mathrm{n}$ (c).

64 Preface, Land Warfare, ibid, p iii. The authors of Land Warfare make frequent reference to Professor Oppenheim's International Law Vol 2 (international law during wartime) (1905 and 1906), in which "he conceived of international law as the empirically identifiable product of the political will of states rather than as a natural feature of life". Book Review, Reisman, "Lassa Oppenheim's Nine Lives" (1994) Yale JIL 255, 264.

65 See also supra, nn 23-31, and accompanying text. Holland notes that usage grew out of "sentiments of humanity, as also of personal honour, reinforced by considerations of general convenience". Preserved for the most part by military tradition, acceptable usage was indicated in these authoritative manuals. T E Holland, op cit supra n 16, pp $290-294$.

66 However, the authors admit that these manuals were published some time before the Geneva Conference of 1906 and the Hague Conference of 1907, reducing their value somewhat as guides for these purposes. Preface, Land Warfare, op cit supra $\mathrm{n} 20$, p iii. TE Holland wrote the British manual of 1904 . Holland notes mildly that the German manual "did not follow the Regulations quite closely". T E Holland, op cit supra n 16, pp 292-293. 


\section{POWS}

The fact that the treatment of POWs had undergone great changes by the time of writing is forcefully made in Land Warfare. ${ }^{67}$ In particular, it is noted, captured soldiers were not deemed to be prisoners of the state until the 17th century. This had obvious implications for their treatment, which had progressed from killing and enslavement, to imprisonment and demands for ransom. ${ }^{68}$ Otherwise, Land Warfare generally parallels the Hague Regulations, eg, with regard to humane treatment, the rules of interrogation, and conditions for the safeguarding of personal belongings. ${ }^{69}$

Preliminarily, it is noted that "[i]t is forbidden to kill or wound an enemy who having laid down his arms, or having no longer means of defence, has surrendered at discretion". ${ }^{70}$ POWs who attempt to escape, however, may be fired upon. ${ }^{71}$ In parallel with Hague Regulation article 8 , unsuccessful escapees are liable only to disciplinary punishment, which is defined negatively in Paragraph 76 of the British manual as excluding a death sentence. Instead,

Punishment for attempted escape usually consists in curtailment of the measure of liberty usually allowed to prisoners, or even of detention. If escapes are of frequent occurrence it is permitted to anticipate further attempts by increasing the measures of security. ${ }^{72}$

In addition to being fired upon during an escape attempt or for resisting guard, POWs could be sentenced to death if convicted by a "proper court ... of an offence punishable by death under the civil or military law of the captor". ${ }^{73}$ This implies that convicted spies may also be POWs. While the authors note that

Paragraph 361: It is of little consequence whether the government imposed by the invader is called military or civil government, for in either case it is a government imposed by the necessity of war...,

they make the ensuing distinction:

${ }^{67}$ The relevant British instructions were contained in "General rules for prisoners of war interned in the United Kingdom". Land Warfare, op cit supra n 20, paragraph $54 \mathrm{n}$ (d).

${ }^{68}$ Land Warfare, ibid, paragraph 54. Improvements in the treatment of POWs have been attributed to changes in their socio-economic value as a labour reserve for the detaining power. See A Rosas, op cit supra n 20, pp 43-75. Much of the credit for specifying and developing the 18th century European laws and customs regarding POWs belongs to the Treaty of Amity and Commerce of 1785 between the United States and Prussia, reprinted in C Parry (ed), The Consolidated Treaty Series. Vol 49 (Oceana Publications, 1969), and cited by A Rosas, op cit supra n 20, pp 349-352. See also G Werner, loc cit supra n 27, pp 16, 94; T E Holland, op cit supra n 16, pp 335 ff.

69 Land Warfare, op cit supra n 20, paragraphs 66-68, and 69-73, respectively. See also paras 82-91 (conditions of internment), paras 92-95 (labour), paras 96-101 (parole), paras 102-109 (bureaux of information), paras 110-111 (prisoner exchange), para 112, (charitable assistance), para 113 (freedom of religion), para 114 (wills, death certificates, burials), paras $115-116$ (repatriation).

$70 \mathrm{Ibid}$, paragraph 50, and Hague Regulations article 23(c). This prohibition, located in Chapter IV of Land Warfare entitled "killing and disabling of enemy combatants", is presumably the first step in the taking of prisoners within the dictates both of the laws in force, and "religion, morality, civilisation, and chivalry". Ibid, paragraph 39.

${ }^{71}$ Ibid, paragraph 74, citing Proceedings of the Hague Conference of 1899, p 144. It is further noted that "a previous summons to halt and to surrender should be given if possible". [Emphasis added.] See also the Brussels Project article 28.

${ }^{72}$ Land Warfare, op cit supra $\mathrm{n} 20$, paragraph 77 . The authors note by way of example that during the Franco-German War of 1870-1871, the Prussian government severely curtailed the movement of captured French officers because of an alleged frequency of escapes. Ibid, $\mathrm{n}(\mathrm{n})$.

$73 \mathrm{Ibid}$, paragraph 79. See also the Oxford Mamal article 23: "[i]ndividuals captured as spies cannot demand to be treated as prisoners of war". The Hague Regulations are silent on this point. With regard to Grischa's sentence of death as a deserter and presumed spy, it is provided in Land Warfare paragraph 64, as follows:

Deserters from the enemy should be treated as prisoners of war, unless special circumstances render it desirable to liberate them. Deserters and subjects of a belligerent captured in the ranks of the enemy have, as already pointed out [in Paragraph 36], no right to claim treatment as prisoners of war, or the benefit of the laws of war.

Emphasis added. Paragraph 36 describes deserters as "traitors to their country". As they "cannot be regarded as enemies in the military sense of the term, [they] cannot claim the privileges of the members of the armed force of the enemy". 
Paragraph 364: ... the civil and penal laws of the occupied country continue as a rule to be valid, the courts which administer them are permitted to sit, and all crimes of the inhabitants not of a military nature or not affecting the safety of the army are left to their jurisdiction.

Paragraph 365: The officers, men and followers of the occupying force are not answerable to the jurisdiction of these courts; they are dealt with by the military law of their army.

The relevance of this distinction will be discussed below.

\section{Spies}

The authors of Land Warfare deal with espionage, and acts of treason which are closely allied with espionage, in Chapter 5. They begin by noting that espionage is "formally sanctioned by the Hague Rules", and further, that "it is lawful to employ spies and secret agents". ${ }^{74}$ Nevertheless, they emphasise that "custom admits their punishment by death". 75

As noted above, Hague Regulations article 29 provides a restrictive, technical definition of a spy, which requires the spy to act clandestinely and under false pretences. ${ }^{76}$ The authors of Land Warfare point out, however that

[A]ny person who makes or endeavours to make unauthorised or secret communications to the enemy, or to collect information secretly for him, is ordinarily spoken of as a spy.

and that the Hague definition "does not cover all such cases". 77 They further distinguish between spies as so defined, and war treason, which latter characterisation is not mentioned in the Hague Rules, but exists in customary international law. ${ }^{78}$

They conclude that

Paragraph 164: An officer or soldier who is discovered in the enemy's line dressed as a civilian, or wearing the enemy's uniform, may be presumed from the circumstances to be a spy, unless he is able to show that he had no intention of obtaining military information.

However, the fact that a person is in his own army's military uniform when caught is not conclusive. ${ }^{79}$ Hence, and in accordance with the Hague Regulations concerning the subject, it would appear that the crucial requirement for conviction as a spy at a Paragraph 169 trial $^{80}$ is proof of intent to obtain enemy military information. Finally, the immunity afforded to a captured enemy spy after a successful espionage operation ${ }^{81}$ does not extend to persons guilty of war treason, who may be arrested at any place or time. $^{82}$

${ }^{74} \mathrm{Ibid}$, paragraphs 155 , and 158, respectively. The authors admit that, while this latter point is controversial to many writers, "military custom has always sanctioned it". Ibid, paragraph $158 \mathrm{n}$ (c).

75 Supra $\mathrm{n} 46$. The Hague Conventions are silent on this point.

76 Supra n 44

77 Land Warfare, op cit supra n 20, paragraph 160

$78 \mathrm{Ibid}$, paragraph 167. War treason, as described in paragraph 445 , includes acts by private individuals or soldiers in disguise which, if done by members of the armed forces, may be perfectly legitimate, for example, damaging the means of communication, assisting the escape of enemy prisoners, fouling water supplies. Should an act not amount to espionage, belligerents may still impose very severe penalties on the basis of war treason. The German military authorities in particular interpreted the concept of war treason harshly. T E Holland, op cit supra n 16, pp 348-349.

79 Land Warfare, op cit supra n 20, paragraph 165. The authors give as examples a soldier admitted behind enemy lines under Red Cross privileges or a flag of truce who then obtains military information. Ibid, paragraph $165 \mathrm{n}$ (b).

80 "As required by Hague Rules, 30. Still less can anyone else be punished without previous trial, which in every case is indispensable". Ibid, paragraph 169 n (a), citing the Hague Conference, 1899, p 146.

81 Who must be granted POW privileges. Ibid, paragraph 170, and Hague Regulations article 31, text quoted supra.

82 Land Warfare, op cit supra n 20, paragraph 171. The authors note, however, that Hague Regulations article 13 does not restrict the benefit of immunity from prosecution to spies who are soldiers. Ibid, paragraph $171 \mathrm{n}$ (c) 


\section{Grischa}

Under military custom and usage as reflected in British, French, and German military practice by World War 1, it would appear that Grischa, the unsuccessful POW escapee, would face disciplinary punishment at most on recapture, which could in his case involve a more severe restriction on his liberty of movement. Further, while the POW is in principle subject to the laws, regulations and orders of the detaining power, he remains under the criminal jurisdiction of his own country. Thus, it is impliedly recognised, through the complete immunity granted in law from prosecution by a detaining power after a successful escape, that the POW is expected to continue to act in the interests of his country of allegiance. ${ }^{83}$ By so doing, he has a positive duty to make the attempt, in order to rejoin his own forces.

As regards Bjuscheff the deserter, he would not be entitled to claim POW treatment, as both the status, and the equivalent treatment were lost by the act of desertion. On the other hand, Paragraph 64 of Land Warfare exhorts commanders to treat deserters as POWs, unless circumstances exist which are more favourable to sending them on their way. ${ }^{84}$ Regarding espionage, usage (which of course has no legal force) also implied that proof of an intent to obtain enemy military information clandestinely was crucial in a conviction for espionage, which in turn relegates the issue of a disguise to a matter of circumstance. ${ }^{85}$

Viewed in this way, Schieffenzahn's Order regarding deserters and spies appears to be much harsher than either the Hague Rules, or military usage, and the refusal by Schieffenzahn to adjust Grischa's identity back from that of Bjuscheff on the bases of "military and political interests", "the prestige of our courts", "the interests of military discipline", and to prevent "prejudice to the State" fully underscores his further opinion that "the legal aspect of the case is of very slight importance". 86 In other words, an intent to spy was presumed simply by the failure of a deserter to report to the military authorities within three days. Thus, no distinction is made between an act which is absolutely prohibited, and an act which both the written and unwritten rules of the day define as resulting from specific circumstances, and which requires intent. While it is of course in the very nature of an absolute prohibition that intent may be irrelevant, the knife twists when Schieffenzahn's subsequent refusal to adjust Grischa's death sentence as a spy to that of disciplinary sanction is based on the dossier's "political nature".

There would be many presumptions favouring the POW attempting to escape: (1) there was a duty to do so; (2) if unsuccessful, disciplinary sanction alone would result; and (3) a complete immunity from prosecution for a successful escape upon subsequent recapture by the enemy would be granted. The fact that Grischa wore Bjuscheff's uniform as a disguise in which to escape would have done nothing to alter this legal scenario, particularly after his former camp guards arrived in Mervinsk to identify him.

${ }^{83}$ A belligerent may however attempt to exert coercive political control over its POWs, particularly when an armed conflict has ideological content. A Rosas, op cit supra n 20, pp 430, 434. See infra n 86.

84 However, "feigned deserters are apt to be treated as spies". T E Holland, op cit supra n 16, p 347.

85 Nevertheless, the necessary mental element may be presumed in the face of a risk known to the accused. Grischa wore Bjuscheff's uniform because of the risk of recapture. Thus, rationally, Grischa could have been convicted for spying in the uniform of Bjuschoff, but only on proof of an intent to obtain military information.

86 Supra n 13. Rosas notes that the growing trend towards "total war" seen in World War 1, in addition to the "relatively high degree of tension between the main protagonists", meant that efforts to exploit POWs politically led to "differential treatment according to national origin". A Rosas, op cit supra n $20, \mathrm{p} 75$. The only tension readily apparent in Zweig's account is of a more personal kind - that between Major-General Schieffenzahn (the son of an Austrian miller and persecuted by the "vons" while at military school), who wielded the civil authority, and His Excellenz Otto von Lychow, Divisional General in charge of troops in transit, Schieffenzahn's superior, and an old Prussian Junker, friend of the Emperor, and "protector of Grischa". See also K Petersen, op cit supra n 8, p 17. 


\section{THE DIVISION OF AUTHORITY IN ENEMY-OCCUPIED TERRITORY}

\section{The Hague Rules}

Zweig locates his plot in the Ob-Ost, which by 1917 chiefly comprised the militarilyoccupied lands of Courland, Lithuania, and Northern Poland. The written and unwritten laws which govern the occupation of enemy territory are thus of relevance in regard to the civil and military administration in place at the time of Grischa's re-arrest and subsequent execution.

The subject of enemy-occupied territory is dealt with in the Hague Regulations articles 42-56. Occupation of enemy territory must first be contrasted with both the act of invasion, and the fact of ownership. Invasion, while usually preceding, or coincident with occupation, may be more transitory in the event, eg, of a special force completing its particular task and moving on. In that event, occupation may be said to be merely temporary. ${ }^{87}$ Similarly, ownership usually occurs through formal annexation consequent to final conquest. ${ }^{88}$ Thus, article 42 of the Hague Regulations provides the following definition:

Territory is considered occupied when it is actually placed under the authority of the hostile army. The occupation extends only to the territory where such authority has been established and can be exercised. ${ }^{89}$

The military occupier is charged with maintaining public order "while respecting, unless absolutely prevented, the laws in force in the country". ${ }^{90}$ This means that the civil and penal laws of the occupied country generally speaking continue in force, even though the native authority can no longer act within the occupied district. The occupier may also, inter alia, collect taxes and other money contributions, ${ }^{91}$ and use state-owned military property. ${ }^{92}$

A further reference to the potentially transitory character of belligerent occupation is apparent in the Hague Regulations article 45, which enjoins the occupier not "to compel the inhabitants of occupied territory to swear allegiance to the hostile power". This prohibition reflects the continuation of the duty of allegiance to the legitimate ruler. Allegiance however is to be contrasted with the transfer of the duty of obedience to the occupier (which the legitimate ruler is now incapable of demanding, anyway). The inhabitants of the occupied area are thus allowed to pursue their lives largely uninterrupted in exchange for submitting to the effective authority exercised by the occupier.

On the other hand, the liberty of the population may be restricted by the power of the occupier to suspend the operation of laws to the extent it considers required for the safety and the success of its operations. Thus, the occupier will frequently replace the actual civil and judicial administration by its own military jurisdiction. As a corollary to this, the occupier may declare certain acts, not forbidden by the ordinary laws of

\footnotetext{
${ }^{87}$ See Land Warfare, op cit supra n 20, paragraph 343. Cf paragraph $343 \mathrm{n}$ (d) (the rules of occupied territory "should be observed as far as possible in territories through which troops are passing").

88 See, eg, T E Holland, op cit supra n 16, p 354.

89 Thus, occupation must not only be acquired, but maintained, Land Warfare, op cit supra $\mathrm{n} 20$, paragraph 350 . It is thus essentially a right of control.

90 [Emphasis added.] Hague Regulations article 43. See also Land Warfare, op cit supra n 20, paragraph 364, quoted supra in text.

91 Hague Regulations articles 48-51, but within strict guidelines. See also Land Warfare, op cit supra n 20, paragraphs 369-372.

92 Hague Regulations article 53, once again within strict guidelines. $C f$ article 52.
} 
the country, to be punishable. ${ }^{93}$ While the right to do so may be viewed as a function of military necessity, and of war itself, a belligerent may also be persuaded to so act far in excess of its rights by the effectiveness of intimidation of the inhabitants. ${ }^{94}$ There are, thus, two separate jurisdictions exercised by the occupier: that over the native population, and that over the occupying troops.

Usage

The authors of Land Warfare deal with the occupation of enemy territory in Chapter VIII. While discussing the Hague Regulations throughout, they make a number of additional, perhaps explanatory, remarks. First, they note that

In the interests of the inhabitants it is most desirable, though in strict law not necessary, that the invader should take measures to make known by proclamation the fact of the establishment of occupation and the area over which it extends. He should at the same time summarise the effects which result from the new state of affairs. ${ }^{95}$

They caution, however that "the occupant ... must not treat the country as part of his own territory". 96 Sovereignty does not pass to the occupant, but is merely "temporarily latent", 97 nor may the occupier alter "the existing form of government, upsetting the constitution and the domestic laws, and ignoring the rights of the inhabitants". 98 On the other hand, the occupier may suspend "political laws and constitutional privileges as a matter of course", 99 and thus may restrict and condition commercial intercourse, impose censorship, control modes of transportation, and restrict freedom of movement. ${ }^{100}$ While religious, educational and medical establishments must be kept open, this is subject to "refraining from reference to politics", and the dictates of military necessity, generally. ${ }^{101}$

These many usages reflect the authors' assertion that an occupying authority is "a government imposed by the necessity of war". 102 As such, the occupier can exert a fairly free hand over any direct relations between it and the inhabitants. This fact, as reflected in the Hague Rules and usages indicated above, has obvious legal and economic consequences. On the other hand,

In return for this considerate treatment it is the duty of the inhabitants to behave in an absolutely peaceful manner, to carry on their ordinary pursuits as far as is possible, to take

${ }^{93}$ See, eg, W E Hall, op cit supra n 19, pp 558-562. Cf Hague Regulations article 23, supra n 35, and, in particular, article 23(h); "Appendix: Correspondence with the Foreign Office respecting the Interpretation of article 23(h) of the Hague Regulations concerning Land Warfare", L Oppenheim, The League of Nations and Its Problems (Longmans, Green and Co., 1919), p 48.

94 Cf W E Hall, op cit supra n 19, pp 570-571. He notes that "rights which are founded upon mere force reach their natural limit at the point where force ceases to be efficient", and likens abusive control mechanisms to "a system of terrorism, ... because an occupying army does not scruple to threaten and to inflict penalties which no government can impose upon its own subjects". Ibid, p 575.

95 Land Warfare, op cit supra n 20, paragraph 347. For example, "in 1870, the Germans generally, but not always, proclaimed military jurisdiction directly they took possession of a locality by reading or posting a notice ... which gave a list of offences against the troops for which the penalty of death would be inflicted". Ibid, paragraph $347 \mathrm{n}$ (c) (citation omitted). See also paragraph 364 , quoted supra in text.

96 Ibid, paragraph 355. Cf Hague Regulations article 55, which specifies that state property must be administered "in accordance with the rules of usufruct".

97 Land Warfare, op cit supra n 20, paragraph 353.

98 Ibid, paragraph 354. Cf W E Hall, op cit supra n 19, p $557 \mathrm{n}$ "l" (a modern example of an assertion of substituted sovereignty occurred in Alsace in 1870); T E Holland, op cit supra n 16, p 361 n 29 (German practice 1914-1918). "Rights of the inhabitants" presumably includes respect for their lives. See Land Warfare, op cit supra n 20, paragraph 383, and Hague Regulations article 46.

99 Land Warfare, op cit supra n 20, paragraph 362.

$100 \mathrm{Ibid}$, paragraphs $373-377$.

$101 \mathrm{Ibid}$, paragraphs 378-380. See the 1864 Geneva Convention articles 3 and 4, and the 1906 Geneva Convention articles 12 and 15. Cf Hague Regulations article 56.

102 See Land Warfare, op cit supra n 20, paragraph 361, quoted supra in text. 
part in no way in the hostilities, to refrain from every injury to the troops of the occupant, and from any act prejudicial to their operations, and to render obedience to the officials of the occupant . Any violation of this duty is punishable by the occupant. ${ }^{103}$

The authors cross-reference this provision to Paragraph 441 , et seq, entitled "The Punishment of War Crimes". Acts relevant to the population of occupied territories include "war rebellion", "espionage and war treason", and "marauding". 104 Paragraph 450 provides that charges of war crimes can carry the death sentence, and may be dealt with under Paragraph 449 either by "military courts or by such courts as the belligerent concerned may determine"". The authors note further that "it would not be in the interests of humanity" to grant a right to such prisoners to claim release at the end of the war, "for otherwise belligerents would be forced to carry out capital punishment in many more cases that is now usually necessary". ${ }^{105}$

\section{Grischa}

In the discussion which immediately precedes, attention has been paid to the rules and theory of belligerent occupation. Its purpose has been to stress that, by the outbreak of World War 1, a certain commonality in European standards and rules reflected the common interests of the major capitalist states. For example, observance of the rules of usufruct, rather than powers of outright disposal, was required regarding the use of state property. Money contributions could be levied from the occupied population, but where private property was in issue, compensation was required. ${ }^{106}$ Where the rules were broken, or simply ignored, elements of conflict inherent to all competitive social relations are in evidence.

In Grischa it is noted that "it did not occur to anyone that the land would ever be evacuated". It was to be instead "a future Prussian province". ${ }^{107}$ The distribution of authority in Ob-Ost was as follows. The office of Major-General Schieffenzahn dealt with all local constabulary matters. The Divisional General von Lychow was the final authority in all military affairs of the staffs of armies in the field quartered in the town, but in them only. ${ }^{108}$ Although the relations between the garrison and field-army were somewhat intertwined regarding Grischa's situation, the power to decide his fate was either the Major General's, as control over non-military movements in the territory (including those of spies and deserters) ${ }^{109}$ was considered a constabulary matter, or the Divisional Head von Lychow's, Schieffenzahn's senior, who was in charge of the court martial of the army headquarters of the area and hence, over escaped prisoners.

With particular regard to the administrative tension occasioned by Grischa's detention, noted above, it is of interest that two major subplots play throughout Zweig's account: (1) the rise of the industrial, militarised European state, ${ }^{110}$ and (2) the conflict occasioned by the rise of the middle classes in Germany to positions of authority." At this point, the statement by Clausewitz that "war is a mere

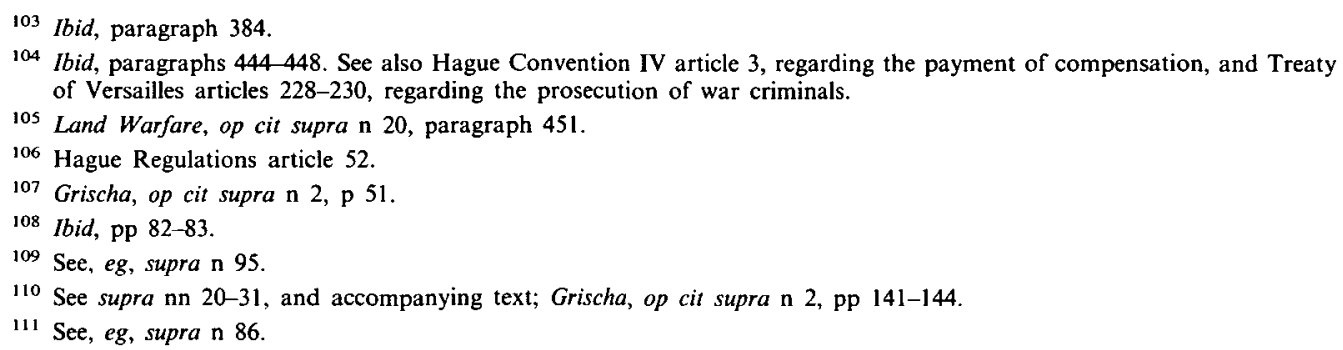


continuation of (peace-time) policy by other means" becomes relevant. ${ }^{112}$ In particular, factors such as a fluctuating class structure (occasioned at least in part by alterations to and within the societal forces of capitalist production) proved influential when the time arrived to adopt a stance of political convenience, not only towards the manner of waging a technologically-advanced war, but also, towards Grischa.

Ultimately, we learn that Grischa's case was not determined by rules concerning escaped POWs, spies, or the administration of occupied territory. ${ }^{113}$ Instead, "the legal aspect of the case" was balanced against "the military and political interests involved", and found to be "of very slight importance". 14 The binding obligations found in the Hague Regulations were thus effectively limited by "the compatibility of the latter with the state's goals", 115 as based on legal theories current in Germany in the period before 1914. This in turn meant that "the fundamental element of the state was power and no law could interfere where clashes of power were at play among states".116

The opposing schools of state community as represented by the development of Hague and Geneva law, and state individuality as interpreted through notions of individual state political imperative, met in Mervinsk regarding Grischa's fate. In particular, the underlying ideological struggle between Schieffenzahn and von Lychow reflected not only an interpersonal tension, but also a tension felt throughout Europe at the time between competing schools of social, political and military thought. In turn, the more jurisprudential concerns inherent in debates over the relationship between law and the state source much of the dialogue. Should conclusions as to the strength of the rule of law in the relationship between Germany and the other belligerents (and within the occupied territory of Ob-Ost) during World War 1 be viewed in this light, it becomes clearer perhaps why Hague law and the developed norms of military usage were not persuasive in Grischa's case. In other words, while the fact of Grischa's second arrest, and trial before execution, appear to have been in conformity with the rules of "civilised" European states, the outcome rested on a known fiction. Grischa thus demonstrates the victory of power over the forces of law, ${ }^{117}$ and Bjuscheff dies a second time.

\section{CONCLUSIONS}

In legal and humanitarian terms, "Grischa had a case". On the other hand, the wartime "necessity" reflected in the execution of "Bjuscheff" was symptomatic of a deeper jurisprudential struggle - that between the state as creator, or as creature, of law. It is now proposed to finalise the conclusions reached thus far.

\footnotetext{
112 C M von Clausewitz, On War, by A Rapoport (ed) (Penguin, reprinted 1968), Book 1, Ch 1, paragraph 24, p 119 , and discussed in A Rosas, op cit supra $\mathrm{n} 20$, p 16.

113 Cf supra $\mathrm{n} 94$, and accompanying text.

114 See supra, text accompanying $\mathrm{n} 13$.

115 A Carty, The Decay of International Law? A Reappraisal of the Limits of Legal Imagination in International Affairs (Manchester University Press, 1986), p 76. While the development of 19th century theories of treaty obligation is beyond the scope of this discussion, Carty notes that a Hegelian school of thought was in vogue at the time in Germany. In reliance on Romantic concepts of identity, states were viewed as existing in a state of nature. This meant that individual state contracts (eg, treaties) could be based neither on a higher law, nor provide the foundation for any universal law. A higher, or universal law simply did not exist. States' rights instead were actualisable only through the individual will of each. A state which could not harmonise its individual political will with that of other states must settle the matter by war. In this way, war could change the law. Thus, "the German jurist was convinced that the convergence of theory and practice was complete". Ibid, p. 77. Cf supra nn 18-20, and 64.

116 A Carty, op cit supra n 115, p 77, citing H von Treitschke, Politik, Band 2 (1900), pp 544-547.

117 See K Petersen, op cit supra n 8, pp 16-17.
} 


\section{Grischa, the Escaped POW?}

According to Hague Regulations, article 4, Grischa the POW is in the protective custody of the enemy state, and "not of the individuals or corps" who capture him. Article 9 states Grischa's obligation on capture (and presumably, re-capture) to give his correct name and rank. Hague Regulations article 8(1) declares that he is subject to the detaining power's laws, regulations, and orders in force, and acts of insubordination may be severely punished. However, he has a duty to escape. ${ }^{118}$ In order not to conflate the categories of POW and deserter (who could not claim POW treatment), article 8(2) allows disciplinary punishment only for an unsuccessful escape attempt. A successful escapee is immune from punishment for the escape, according to article 8(3).

There is no express provision for the humanitarian treatment of POWs in Geneva law during World War 1, other than that given in Hague Regulations article 4: "they must be humanely treated". Nevertheless, the International Committee for the Red Cross play an active role regarding this specific issue on the conditional authority contained in Hague Regulations articles 14 and 15. Despite the fact that the 1906 Geneva Convention brought voluntary humanitarian assistance under the control of the belligerent employing it, visits to POW camps became a means by which ICRC delegates could observe the application of the Hague Regulations. ${ }^{119}$ ICRC delegates visit Grischa in his second place of internment prior to his execution, and conclude that the prison is humanely run.

The British Manual of Land Warfare conforms with the Hague position on POW escape attempts, adding that "disciplinary" punishment does not include the death sentence. ${ }^{120}$ However, POWs may be fired upon during an escape attempt, and may be sentenced to death for "an offence punishable by death under the civil or military law of the captor". ${ }^{21}$ This implies for example that POWs may be convicted of spying.

Therefore, the maximum sentence available in law and usage for Grischa's failed escape attempt is disciplinary punishment. His failure to give his true name and rank on re-capture is likely to result only in a curtailment of advantages.

\section{Bjuscheff, the Spy and Deserter?}

Espionage is regulated by Hague law, and article 29 of the Hague Regulations strictly defines a spy as a soldier in disguise who penetrates into the zone of operations of the enemy with the intention of obtaining enemy military information for communication. Article 31 of the Regulations provides that a successful espionage operation meets with the same immunity from punishment as a successful escape attempt.

The authors of Land Warfare imply that the Hague definition is too restrictive, and distinguish between spies as so defined, and war treason. With regard to spying, they note that there are occasions when a military spy may be caught wearing his own uniform, ${ }^{122}$ and focus more on the element of intent. Therefore, an alleged spy must show that he has no intention of obtaining military information for purposes of espionage. As to war treason, the Hague Regulations are silent. Nevertheless, this category exists in customary international law. Thus, when an act does not amount to espionage, belligerents may still impose very severe penalties on the basis of war treason, which offence carries no immunity from punishment. ${ }^{123}$

\footnotetext{
118 Supra nn 67-73, and accompanying text.

119 Supra nn 61-62, and accompanying text.

120 Supra nn 63-66, and accompanying text.

121 Supra n 73, and accompanying text.

122 Supra n 79.

123 Supra nn 78, and $80-82$.
} 
Deserters are dealt with as follows. Deserters, as traitors to their country, lose any right to claim either the status or treatment of POWs because they can no longer be regarded as enemies in the military sense. ${ }^{124}$ This loss of status implies also that the ICRC has no authority to care for them, unless they fall within the categories of sick and wounded protected through the Geneva Conventions of 1864 and 1906. Nevertheless, and according to usage, deserters should be treated as POWs, though one commentator remarks that feigned deserters may be treated as spies and shot. ${ }^{125}$

Grischa is re-captured after his escape attempt wearing a Russian uniform, though not his own, and he gives a false name and rank. Thus, the issue of disguise is relevant. On the other hand, he quickly reveals his true identity and status, which are confirmed by his former camp guards. The problem then becomes to ascertain whether evidence exists to prove he possesses an intent to obtain enemy military information, which arguably could conflate his status as an escaping POW with that of a spy. Evidence of an intent to spy during his escape would deprive him potentially of POW treatment, ${ }^{126}$ and opens the door to the death penalty. ${ }^{127}$

\section{War Law, or War Politics?}

The basic principles of the laws of armed conflict were formulated primarily during the 18 th and 19th centuries among European states which shared growing levels of economic inter-dependence. The monopolisation of the twin forces of production and capital implicated concurrent developments in arms technology as well as efforts to codify humane measures of restraint in the means and methods of warfare. The written and unwritten rules which resulted applied among those "civilised" capitalist states which possessed a degree of parity in (industrialised) armaments. ${ }^{128}$

By implication, Bentham's project of an international code took capitalist technology into account. Bentham proposed that each state should restrain its choice of the means and methods of warfare, albeit within confines of "the regard which is proper to its own well-being". ${ }^{29}$ The implication thus is that reciprocity in restraint is to the ultimate benefit of industrialised states. It is therefore not entirely surprising that the more long-term interests of state survival among industrialised states should be reflected in the Hague and Geneva instruments. However, by the end of the 19th century, neo-Hegelian views current in Germany undermined the consensus regarding treaty obligation. The thesis that international restrictions such as those applicable during war could not plausibly be characterised as law, in conjunction with a superficial reading of the Clausewitzian view of war as an extension of (peace-time) policy, ${ }^{130}$ meant that any analogy between the obligations inherent in municipal law contracts and international treaties was theoretically unsupportable. ${ }^{131}$ The resulting dialectical theory of war escalation thus rested on the view that, as the state stood above its treaties, it did "not need to seek objective standards of behaviour"132

124 Supra $\mathrm{n} 73$.

125 Supra n 84.

126 Oxford Manual article 23, supra n 73.

127 Supra text accompanying n 73.

${ }^{128}$ Supra n 20, and accompanying text. Thus, the Lieber Code, applicable during the American Civil War, corresponded to the customary laws of war. Supra nn 24-27, and accompanying text. See also supra nn 31 , and $48-49$, and accompanying text.

129 Supra nn 18-19, and accompanying text. Arguably, this view is particularly tenable when assessments of the balance in material force affect the utility of war as an arm of the law.

130 Supra nn 112, and 115, and accompanying text.

131 See A Carty, op cit supra n 115, p 75.

132 Ibid, p 76, citing E Kaufmann, Das Wesen des Volkerrechts und die Clausula rebus sic stantibus (1911), p 204. Thus, a self-determining state, as a subject, determines its conduct from values within itself. 
outside itself. The effect of this was to make the obligations contained in Hague law and military usage a matter of self-regulation, and hence, of political self-interest. ${ }^{133}$

\section{Grischa? Bjuscheff?}

When it is put to Schieffenzahn that "the matter had gone far beyond a mere question of jurisdiction", as an innocent man was being sent to his death, Schieffenzahn characterises Grischa/Bjuscheff as "a Russian deserter, who had so disgracefully abandoned his post in the prison camp", and adds, "if the German soldier refuses to obey orders, he is shot". 134

According to the logic of the executioner, there is no need to treat Grischa as an enemy in the military sense, if one assumes that desertion is roughly equivalent to "abandonment". As deserters cannot claim either the status or treatment of POWs, there is no need - legal or otherwise - to consider Hague definitions of espionage. ${ }^{135}$ Schieffenzahn thus assimilates Grischa's status as an escaped POW with that of a deserter, a point which Hague Regulation article 8 was intended to avert. ${ }^{136}$ To conflate Grischa's status and behaviour with that of a German soldier is somewhat disingenuous, however. In common with the German soldier, Grischa the POW shares a duty of obedience to Germany, which in Grischa's case is transitory. On the other hand, Grischa owes a continuing duty of allegiance to Russia which implicates the duty to escape. ${ }^{137}$

Further, the Order under which Grischa/Bjuscheff is convicted and executed for espionage consists of an absolute prohibition applicable specifically to "Russian deserters". ${ }^{138}$ As Russia was removing itself from the "common European heritage", 139 the potential spread of a spirit of revolt into the rest of Europe caused great alarm. ${ }^{140}$ When coupled with the dictates of occupational security in Ob-Ost, there was thus perhaps even less reason of a "political" nature to adhere to Hague obligations - selfregulatory or otherwise.

As discussed earlier, the maintenance of control over occupied territory must be effective, ${ }^{141}$ and it is not at all uncommon for the inhabitants of enemy-occupied territory to suffer various forms of intimidation, the force behind which serves also to keep the occupying army disciplined. It must thus be queried whether the "political necessity" of executing Grischa was sourced ultimately in these manifold "interests of discipline". ${ }^{142}$ Nevertheless, it was difficult to find among those stationed in the garrison a company willing to shoot Grischa. Instead, a Bavarian machine-gun battalion, sent back from the front for delousing and re-equipping prior to transport to the Flanders fighting, agree to execute Bjuscheff in exchange for four bottles of schnapps. Its men have an average age of 20 years. ${ }^{143}$

\footnotetext{
133 This view is to be contrasted with the equally contemporaneous view of international law as "the empirically identifiable product of the political will of states". Book Review, Reisman, loc cit supra n 64 .

134 Grischa, op cit supra n 2, p 222.

135 Supra $\mathrm{n} 73$.

136 Supra $\mathrm{n}$ 38. Although Grischa escaped his camp in order to go home, his POW status presumably would continue until his escape attempt succeeded, at which point he would become a deserter.

137 Supra nn 67-73, and accompanying text.

${ }_{138}$ Supra n 9. Cf supra $\mathrm{n} 86$. It could be argued that foreign deserters present in Ob-Ost would be likely to be Russian.

139 Supra n 33, and accompanying text.

${ }^{140}$ In many instances, this was due in large part to the sheer duration of the war. See, eg, Grischa, op. cit. supra n 2 , pp 102, 129-132, and 311 .

141 Supra nn 89-94, and accompanying text.

142 Grischa, op cit supra n 2, pp 233-235, presumably "pour encourager les autres".

143 Ibid, pp 312-314.
} 